\title{
PENGGUNAAN DATA PENGINDERAAN JAUH DALAM PERENCANAAN PEMBANGUNAN PERMUKIMAN TRANSMIGRASI
}

\author{
Oleh: Wagiran
}

\begin{abstract}
$\overline{\text { ABSTRACT }}$
There are some steps to operate the programme of transmigration residential planning. The first stage of the step i.e. to confirm the fix area of transmigration location. The physical information of the area is obtainble from the image of satellite remote sensing as well as aerial photograph interpretation. Not all of the step in the activity needs the additive data which obtainable from aerial photograph. The step which need the additive data from aerial photograph i.e. both the long term and semi long term planning "SKPT" and "RTKIM"
\end{abstract}

\section{$\overline{\text { ABSTRAK }}$}

Ada banyak tahap yang harus dikerjakan dalam program perencanaan pemungkinan transmigrasi. Tahap awal dari kegiatan ini adalah menentukan area untuk lokasi transmigrasi. Informasi fisik area tersebut dapat diperoleh dari data penginderaan jauh, baik citra satelit maupun foto udara. Tidak semua tahap dalam kegiatan ini memerlukan data bantu foto udara. Tahap yang memerlukan data bantu foto udara adalah tahap : perencanaan jangka panjang, perencanaan jangka menengah, "SKPT" dan "RTKIM".

\section{$\overline{\text { PENDAHULUAN }}$}

\section{$\overline{\text { Latar Belakang }}$}

Pada dasarnya kebijaksanaan Pembangunan Transmigrasi sampai dengan Repelita V dan memasuki Repelita VI semakin mantap. Hal tersebut dapat tercermin pada orientasi dan sasaran utamanya yaitu peningkatan taraf hidup masyarakat transmigrasi melalui pengembangan berbagai macam pola pemukiman dan usaha.
Konsekuensi dari pengembangan berbagai pola tersebut menuntut aparat Departemen Trasmigrasi dan Pemukiman Perambah Hutan dan instansi terkait untuk bekerja secara lebih sistematis dan terencana. Sebab keberhasilan pembangunan transmigrasi sangat ditentukan oleh kegiatan perencanaannya.

Dalam kegiatan perencanaan pembangunan permukiman transmigrasi banyak unsur/faktor yang harus diselesaikan baik itu yang bersifat koordinatif antar instansi pemerintah, 
dengan pihak swasta dan atau masyarakat, terutama dalam penyediaan areal yang sudah bebas dari segala hak maupun perencanaan yang terpadu antara pembangunan pemukiman transmigrasi dengan persiapan calon transmigrasi di daerah asal. Hal ini untuk menghindari terjadinya sengketa tanah pada waktu permukiman sudah di tempati oleh transmigran dan juga untuk menciptakan kesesuaian antara pembangunan permukiman dengan kesiapan calon transmigran berdasarkan pola yang dikembangkan.

Tahap awal dari kegiatan perencanaan pembangunan permukiman trasmigrasi adalah menentukan peruntukan pencadangan areal untuk lokasi transmigrasi yang sesuai dengan pola pemukiman dan usaha yang akan dikembangkan. Sampai saat ini pola pemukiman transmigrasi yang telah dan akan dikembangkan antara lain pola Tanaman Pangan, Pola Perkebunan, Pola Hutan Tanaman Industri, Pola Perikanan (tambak dan nelayan). Pola Jasa dan Industri dan Pola Peternakan dan pola-pola lain yang memungkinkan untuk dikem bangkan seperti agro marine, agro estate, agro industri dan lain-lain.

Setiap pola pemukiman transmigrasi mempunyai prosedur, kriteria dan standard tersendiri. Namun demikian secara umum dapat diklasifikasikan dalam tahap perencanaan sebagai berfkut : perencanaan jangka panjang (phase I), perencanaan jangka menengah (phase II) yang ditindaklanjuti studi kelayakan pemukiman transmigrasi (SKPT/studi phase II A), rencana tehnik, pemukiman transmigrasi (RTKIM/studi phase II B1), rencana tehnik pengerahan (RTRAH/ studi phase II B2), rencana Tehnik pembinaan (RTBIN/studi phase II B3) dan perencanaan tahunan (phase III).

Untuk mendapatkan informasi fisik yang cepat dan akurat dengan biaya yang relátif ringan, pada tahap perencanaan diperlukan data bantu berupa data penginderaan jauh yang berskala kecil yaitu citra satelit dan yang berskala besar yaitu foto udará. Namun demikian tidak setiap tahapan perencanaan memerlukan data bantu tersebut. Sedangkan yang memerlukan data bantu photo udara adalah pada perencanaan jangka panjang, perencanaan jangka menengah, SKPT dan RTKIM.

\section{TAHAPAN PERENCANAAN PEMBANGUNAN PERMU - KIMAN TRASMIGRASI}

Perencanaan pembangunan permukiman transmigrasi dilakukan melalui pendekatan sektoral, pengembangan wilayah, pengembangan sumber daya manusia dan pengembangan kelembagaan. Didalamnya terdiri dari 3 (tiga) phase perencanaan yaitu phase I, II dan III. Masingmasing phase mempunyai sasaran dan tujuan yang berbeda namum saling terkait. 


\section{Perencanaan Phase I}

Proses perencanaan pada phase ini terdiri atas kegiatan perencanaan umum dan seleksi lokasi yang berorientasi secara spesifik yaitu pembangunan transmigrasi Hasilnya adalah rencana jangka panjang dan rencana jangka menengah.

Rencana jangka panjang mempunyai tujuan untuk memberikan arah bagi penyelenggaraan transmigrasi pada kurun waktu 25 tahun yang akan datang. Arahan tersebut memperlihatkan peran dan kedudukan penyelenggaraan transmigrasi terhadap berbagai kegiatan pembangunan sektor lain, baik yang dilakukan oleh pemerintah, swasta maupun masyarakat dalam lingkungan nasional. Dengan demikian beberapa tujuan transmigrasi secara analisis dapat digambarkan antara lain: peningkatan pembangunan daerah, pemerataan pembangunan daerah, peningkatan kesatuan dan persatuan bangsa serta pertahanan dan keamanan nasional (hankamnas). Perencanaan fisik dapat menggunakan tingkat kerincian yang digambarkan pada peta skala 1:500.000. Perencanaan jangka panjang memberikan gambaran tentang kontribusi pembangunan transmigrasi terhadap pembangunan nasional, daerah maupun sektor lainnya. Masing-masing kontribusi dirinci kedalam rencana jangka panjang dievaluasi setiap 5 (lima) tahun.
Rencana jangka menengah digunakan sebagai pedoman untuk penyusunan program dan proyek tahunan baik Studi Kelayakan Pemukiman Transmigrasi (SKPT), Rencana Teknik Penyiapan Pemukiman (RTKIM), Rencana Teknik Pengerahan (RTRAH), dan Rencana Teknik Pembinaan (RTBIN), maupun program/proyek implementasi. Tingkat kerincian peta yang digunakan pada rencana jangka menengah adalah skala 1:100.000 s/d 1: 250.000, dengan demikian telaahan fisik akan lebih menonjol dibandingkan dengan analisis sosial dan ekonomi. Rencana Jangka Menengah memuat rekomendasi sebagai berikut :

1. Rekomendasi lokasi/kawasan yang dapat diprogramkan bagi kegiatan perencanaan lebih lanjut berupa studi kelayakan dan rencana teknis, yang dirinci menurut tahun anggaran dan pola usaha pokoknya ;

2. Rekomendasi tentang penyelesaian tentang status areal, dalam bentuk pengurusan hak pencadangan areal dengan maksud untuk membebaskan pencadangan areal bagi instansi/unsur lain dan hak rakyat;

3. Memberi beberapa alternatif rencana dalam hal keterbatasan anggaran ;

4. Memberikan rekomendasi mengenai aspek menejemen dan ketatalak-sanaangunamenunjang pelaksanaan program dan pencapaian sasaran. 


\section{Perencanaan Phase II}

Perencanaan phase II merupakan perencanaan teknis lokasi yang meliputi SKPT (studi phase II A), RTKIM (studi phase II B1), RTRAH (studi phase II B2), dan RTBIN (studi phase II B3).

SKPT merupakan salah satu persyaratan penting dalam proses penyusunan rencana teknis tahap berikutnya, karena kegiatan ini mempunyai tujuan untuk menghitung kelayakan program transmigrasi dengan pola tertentu di lokasi tertentu yang mencakup perhitungan kelayakan usaha bagi kepentingan swasta dan kepentingan transmigran sebagai satu kesatuan. Hasil SKPT yang positif dapat ditindaklanjuti dengan tahap berikutnya yaitu RTKIM, RTRAH dan RTBIN, namun demikian pada tulisan ini hanya akan dibicarakan RTKIM. Sedangkan hasil SKPT yang negatif tidak dapat dilanjutkan dengan tahap berikutnya. Pada dasarnya setiap SKPT pola tertentu mempunyai prosedur, kriteria dan standard tersendiri, namun demikian secara umum dapat diuraikan secara deskriptif yang bersifat arahan prinsip yang berlaku untuk semua pola pemukiman.

Rencana Teknis Penyiapan Pe mukiman (RTKIM) meliputi rencana teknik ruang (tata guna lahan), rencana tapak jalan/jembatan, prasarana lainnya (termasuk irigasi) dan penyediaan air bersih. Disamping itu juga menetapkan berbagai metode penyiapan lahan yang terkait dengan potensi sumberdaya alam dan lingkungan. RTKIM memberikan rekomendasi teknik fisik, berupa penataan ruang. teknik/metode penyiapan pemukiman, penyiapan bangunan sarana air bersih dan sebagainya termasuk penyelesaian status lahan dan pengamanannya serta pelestarian lingkungan.

Untuk - menggambarkan seluruh satuan pemukiman, RTKIM disusun pada tingkat ketelitian yang dituangkan pada peta skala 1:10.000 s/d 1:5.000. Di samping itu dilengkapi dengan :

a. Rencana teknik detail untuk rencana tapak/teknis penggunaan lahan disusun pada peta skala 1:5.000 $\mathrm{s} / \mathrm{d} 1: 2.000$

b. Rencana teknis jalan (penghubung dan poros) disusun pada peta skala 1: 1.000

Dalam rangka penyusunan struktur ruang dan tata ruang pemukiman detail maupun rencana teknik bangunan dan prasarana pemukiman serta sarana fisik pemukiman lainnya, secara umum dianalisa berdasarkan pada peta dan informasi dari SKPT. Bentuk rekomendasi dari RTKIM adalah :

a. Desain tata ruang pemukiman detail, dalam skala 1:10.000 s/d 1: 2.000, beserta uraian proses pengembangannya; 
b. Desain tata ruang usaha tani (khusus untuk kegiatan usaha pertanian), sebagai penjabaran dari studi kelayakan ;

c. Rencana teknis jaringan jalan dan prasarana, disertai deskripsi, peman faatan, pemeliharaan dan peningkatannya ;

d. Desain rencana tapak lahan fasilitas umum dan lahan penyangga, disertai deskripsi mengenai pemanfaatan, pemeliharaan dan pengembangannya ;

e. Sistem dan metode pembukaan, pembangunan, dan pengolahan pemukiman dengan deskripsi teknik operasionalnya ;

f. Rekomendasi tentang pemeliharaan dan peningkatan prasarana dan sarana fisik ;

g. Rekomendasi umum tentang pembinaan dan pengembangan kegiatan usaha yang terkait dengan aspek fisik ;

h. Rekomendasiyangterkaitdengan analisa mengenai dampak lingkungan.

\section{Perencanaan Phase III}

Penyusunan program pada phase III merupakan kegiatan perencanaan tahunan yang intinya adalah menetapkan lokasi program, menyangkut persebaran lokasi/kawasan, pola kegiatan usaha pokok yang menyangkut seluruh karakteristik penyelenggaraan transmigrasidan berbagai sasaran program dalam bentuk ukuran mutu. Kegiatan ini didasarkan pada hasil SKPT dan rencana teknis baik di bidang penyiapan pemukiman, pengerahan maupun pembinaan dan penetapan skala prioritas yang dihasilkan dari optimalisasi faktorfaktor berikut :

1. Ketersediaan anggaran dan pendanaan, baik yang dapat disediakan oleh pemerintah (APBN dan APBD), kredit dari lembaga keuangan (luar dan dalam negeri), bantuan dari lembaga tertentu, investasi swasta dan modal/investasi masyarakat ;

2. Kebijakan tertentudaripemerintah yang merupakan arahan, yang dengan sendirinya diikuti oleh dukungan penyediaan anggaran, seperti penetapan prioritas pengembangan pada daerah tertentu dan atau pengembangan suatu komoditi atau kegiatan usaha tertentu ;

3. Kendala organisasi dan ketatalaksanaan yang secara menonjol akan menentukan kemampuan melaksanakan beban tertentu dan atau kekuatan kelembagaan yang menyebabkan perlunya pemerataan beban tugas;

4. Peluang untuk melakukan pemilihan dan penggunaan teknologi, teknik dan metode tertentu sehingga dapat meningkatkan kemampuan didalam pelaksanaan tugas. 


\section{PERANAN DATA PENG- INDERAAN JAUH DALAM PERENCANAAN PEMBA- NGUNAN PERMUKIMAN TRANSMIGRASI}

\section{Pengenalan Teknologi Peng- inderaan Jauh}

Penginderaan jauh atau "Remote Sensing" atau "Teledetection" diartikan sebagai suatu cara untuk memperoleh informasi atau data dari suatu obyek di permukaan bumi tanpa mendatangi obyek tersebut. Obyek yang menjadi perhatian berupa unsur-unsur permukaan bumi seperti air, tumbuh-tumbuhan dan tanah.

Metode penginderaan jauh dapat dibagi menjadi dua, yaitu :

1. Metode rekaman pasif, dimana perekaman didasarkan atas refleksi (pantulan) radiasi matahari. Sensornya dapat berupa scanner atau kamera.

2. Metode rekaman aktif, yang banyak dikenal dengan citra radar dengan menggunakan kaidah intensitas gelombangyang dipantulkan oleh obyek yang direkam oleh sensor kemudian dipantulkan.

Dari berbagai satelit yang diorbitkan untuk pengambilan data sumber daya alam, Landsat (NASA-USA) dan disusul SPOT (Perancis) adalah satelit yang paling banyak dipakai datanya. Data yang didapat dari citra satelit memungkinkan kita untuk mengamati suatu daerah berulang kali, dalam periode yang relatif singkat dan dapat lebih menghemat biaya bila dibandingkan dengan foto udara. Dengan demikian citra satelit sangat baik untuk mengamati data yang sifatnya dinamik, sedangkan foto udara lebih cocok untuk mengamati data yang statik.

\section{Aplikasi Data Penginde- raan Jauh Dalam Perenca naan Permukiman Transmi-} grasi

Perencanaan pembangunan pemukiman transmigrasi selama ini berdasarkan pada hasil Reppprot (Regional Physical Planning Programe for Trasmigration). Di mana Repprot merupakan suatu proyek kerjasama antara Departemen Trasmigrasi dengan Pemerintah Inggris, bertujuan untuk membuat informasi dasar yang rasional pada tahap perencanaan regional dan terutama untuk penentuan lokasi transmigrasi yang dilakukan secara manual.

Perekaman kegiatan Reppprot ditekankan pada :

1. Memetakan secara teliti daerah hutan yang potensial sebagai "biogetic resource" yang dilestarikan dan lahan yang digunakan sebagai daerah konservasi untuk menjaga erosi lahan.

2. Memetakan lahan yang potensial untuk digunakan sebagai pertanian, perkebunan, dan penggunaan yang lain. 
Hasilnya berupa peta yang menunjukkan spesifikasi suatu daerah yang homogen yang dikenal dengan "land system". Land system merupakan hasil proses dari analisis berbagai data informasi berupa foto udara, foto satelit, peta kerja lapangan dan merupakan salah satu rangkaian proses untuk mencari lahan yang cocok untuk dikembangkan sebagai daerah transmigrasi tanaman pangan. *

Tahapan dalam proses analisis daerah potensial lahan untuk lokasi trasmigrasi adalah :

1. Membuat peta "land form" dari foto udara, foto satelit, peta topografi dan penelitian lapangan.

2. Membuat peta "land system" yang merupakan hasil proses dari penampalan (overlap) bebera peta antara lain: peta vegetasi, peta iklim, peta litologi dan peta tanah.

3. Membuat peta "land suitability" dari peta "land system" yang diberi masukan peta penggunaan lahan sekarang (Existing land use) atau dengan mempertimbangkan masukan " persyaratan tumbuh untuk suatu jenis tanaman tertentu" akan didapatkan lahan yang cocok untuk dikembangkan dengan jenis tanaman tertentu.

4. Membuat "Recomended Development Area/RDA"berdasarkan"land suitability" yang diberi masukan "status lahan". Informasi status lahan berasal dari berbagai instansi yang
terkaitdenganDepartemen Transmigrasi.

Namun demikian Hardi Koesalamwardi mengemukakan bahwa informasi yang diperoleh dari peta reppprot datanya sebagian sudah kedaluwarsa, oleh karena itu perlu ditunjang data penginderaan jauh untuk mendapatkan informasi "land cover" yang mutakhir sehingga dapat mempertajam analisa dalam proses perencanaan pemukiman trasmigrasi.

\section{KESIMPULAN DAN SARAN}

Proses perencanaan pemukiman transmigrasi adalah sangat komplek. Berbagai macam data dan informasi dalam tingkat ketelitian diperlukan dalam perencanaan transmigrasi. Proses perencanaan harus dilakukan dalam waktu yang relatif singkat tanpa meninggalkan pentahapan yang telah dilakukan. Oleh karena cepatnya perkembangan teknologi komputer dan perangkat lunaknya yang dipakai dalam proses digitasi data penginderaan jauh maupun yang lain maka hasilnya lebih tepat, sehingga dengan demikian teknik penginderaan jauh dapat banyak berperan dalam perencanaan pemukiman transmigrasi.

Beberapa data reppprot yang sudah dianggap kedaluwarsa perlu ditunjang dengan data penginderaan jauh yang mutakhir dengan menggunakan Sistem Informasi Geografi (SIG). 


\section{DAFTAR PUSTAKA}

Departemen Trasmigrasi, 1992. Peraturan Menteri Transmigrasi No. PER 115/MEN/1992 Tentang Pedoman Induk Penyelenggaraan Transmigrasi, Jakarta.

-1992. Penyiapan Pemukiman Trasmigrasi Dalam Angka, Jakarta: Ditjen Pankim.

- 1990. Regional Physical Planning Programme For Transmigrasi (Reppprot), Jakarta.

Suharso, 1992. Aplikasi Remote Sensing dan GIS Pada Perencanaan Permukiman Transmigari Disampaikan dalam Seminar dan Lokakarya Perencanaan Permukiman Transmigrasi Jakarta: Ditjen Penyiapan Pemukiman Departemen Trasmigrasi.

Hardi, Koesalamwardi. 1992. Penginderaan Jauh Perkembangan dan Aplikasinya. Disampaikan dalam Seminar dan lokakarya Perencanaan Permukiman Transmigrasi. Jakarta: Ditjen Penyiapan Pemukiman Departemen Transmigrasi. 